\section{ANALISIS PENGARUH PEMBANGUNAN JALAN LINGKAR \\ LUAR TIMUR SURABAYA TERHADAP NILAI TANAH DI SEKITARNYA}

\author{
Gigih Bambang Sutarji ${ }^{1, *)}$, I Nyoman \\ Dita Pahang Putra ${ }^{2)}$ dan Anna \\ Rumintang Nauli ${ }^{3 \text { ) }}$ \\ ${ }^{1}$ Universitas Pembangunan Nasional \\ "veteran" Jawa Timur, \\ gigih.bams@gmail.com \\ ${ }^{2}$ Universitas Pembangunan Nasional \\ "veteran" Jawa Timur, \\ putra_indp.ts@upnjatim.ac.id \\ ${ }^{3}$ Universitas Pembangunan Nasional \\ "veteran" Jawa Timur, \\ anna.ts@upnjatim.ac.id
}

\section{ABSTRAK}

Peningkatan aktivitas Kota Surabaya menyebabkan peningkatan kebutuhan pada aksesibilitas transportasi, Pemerintah Kota Surabaya menjawab tuntutan tersebut dengan pembangunan Jalan Lingkar Luar Timur (JLLT). Pembangunan akses jalan baru tersebut dinilai akan berpengaruh dan menyebabkan perubahan terhadap beberapa hal di wilayah sekitarnya, salah satunya adalah nilai tanah. Maka dari itu penelitian ini dilakukan untuk mengetahui besar pengaruh yang di akibatkan pembangunan JLLT. Wilayah yang menjadi subjek di penelitian ini terdiri dari 4 Kelurahan yaitu Kelurahan Bulak, Tanah Kali Kedinding, Kedung Cowek, Tambak Wedi. Data nilai tanah yang digunakan dalam penelitian ini diperoleh dari Badan Pengelolaan Keuangan dan Pajak Daerah (BPKPD) Kota Surabaya yang selanjutnya dipetakan sesuai zona nilai tanah (ZNT) untuk mendapatkan nilai indikasi rata-rata (NIR) tiap tahun sehingga siap untuk di analisis. Metode analisis yang digunakan adalah regresi linier untuk mengetahui besar pengaruh pembangunan terhadap nilai tanah, sedangkan untuk melihat pola
\end{abstract}

perubahannya menggunakan analisis grafik. Dari analisis regresi didapatkan besar pengaruh pembangunan JLLT sebesar $6.28 \%$ dan berpengaruh positif terhadap nilai tanah atau jika jarak lokasi tanah semakin besar maka nilai akan meningkat.

Kata Kunci : Aksesibilitas, Nilai tanah, NIR, ZNT.

\section{ABSTRACT}

The increasing activity of the city of Surabaya has led to an increase in the need for transportation accessibility, therefore the city government of Surabaya has responded to these demands by building the Out East Ring Road (JLLT). The construction of the new access road is considered to have an effect and cause changes to several things in the surrounding area, one of which is the value of land. Therefore, this study was conducted to determine the magnitude of the influence caused by the construction of the JLLT. The areas that were the subject of this study consisted of 4 villages, namely Bulak, Tanah Kali Kedinding, Kedung Cowek, Tambak Wedi. The land value data used in this study were obtained from the Surabaya City Regional Financial and Tax Management Agency (BPKPD) which is then mapped according to the land value zone (ZNT) to obtain the average indicated value (NIR) each year so that it is ready for analysis. The analytical method used is linear regression to determine the influence of development on land values, while to see the pattern of changes using graph analysis. From the regression analysis, it was found that the influence of the construction of the JLLT was $6.28 \%$ and had a positive effect on the value of the land or if the distance to the location of the land was greater, the value would increase. 
Keywords : Accessibility, Land value, NIR, ZNT.

\section{PENDAHULUAN}

Peningkatan aktivitas Kota Surabaya semakin meningkat yang berdampak pada tuntutan dan permintaan dalam berbagai aspek yang begitu besar, seperti meningkatnya kebutuhan lahan terutama untuk kegiatan transportasi, perumahan, pendidikan, industri, pertokoan. Salah satu tuntutan kebutuhan transportasi adalah jalan raya sebagai penghubung antara lokasi satu dengan lokasi lainnya (Harum dan Sutriani, 2017).

Surabaya sebagai kota terbesar kedua di Indonesia menyebabkan perkembangan penduduknya begitu pesat. Akibat perkembangan tersebut tuntutan kepada pemerintah akan permintaan atas pengadaan, perbaikan dan pelayanan sarana dan prasarana transportasi meningkat, baik dari kuantitas maupun kualitas. Ketersediaan infrastruktur transportasi yang berupa jalan juga menunjang aksesibilitas dan mobilitas penduduk dalam berbagai aktivitas kegiatan perkotaan, oleh karena itu prasarana jalan menjadi salah satu kebutuhan penting.

Pemerintah Kota Surabaya menjawab tuntutan kebutuhan transportasi dengan rencana pembangunan Jalan Lingkar Luar Timur (JLLT). Rencananya jalan ini akan membentang dari kawasan Suramadu hingga Gunung Anyar dan diusahakan dapat beroperasi pada tahun 2020. Jalan ini diharap dapat membantu mengurangi kemacetan di Surabaya tengah dan jalan Middle East Ring Road(MERR) yang semakin padat dan meningkatkan kualitas kehidupan masyarakat yang berada di sekitar wilayah yang dilalui proyek pembangunan Jalan Lingkar Luar Timur Surabaya (Faiq, 2019).

Meskipun pembangunan Jalan Lingkar Luar Timur masih baru saja berlangsung tidak menutup kemungkinan pembangunan jalan tersebut dapat mempengaruhi kondisi daerah sekitarnya. Seiring berjalannya pembangunan Jalan Lingkar Luar Timur wilayah di sekitarnya diperkirakan mengalami perubahan tata guna lahan. Pembangunan Jalan Lingkar Luar Timur yang akan meningkatkan aksesibilitas terhadap kawasan yang dilaluinya dan akan mengubah tata guna lahan dari yang awalnya berupa kawasan pertambakan dan persawahan menjadi kawasan yang lebih padat karena aksesibilitasnya yang baik terhadap wilayah di sekitarnya. Hal ini didukung dengan teori transportasi dan tata guna lahan, yaitu akibat dari perbaikan prasarana transportasi berupa jalan yang berkaitan dengan perubahan tata guna lahan berdampak pada perubahan nilai tanah (Harum dan Sutriani, 2017).

Nilai tanah adalah ukuran kemampuan tanah memproduksi sesuatu yang secara langsung memberikan keuntungan ekonomis (Rahayu, 2009). Ada beberapa teori yang menjelaskan tentang nilai tanah, tetapi hampir semua teori tersebut mengemukakan, bahwa ada keterkaitan antara lokasi tanah dengan nilai tanah. Beberapa teori tersebut menjelaskan bahwa daya tarik dari suatu tanah menjadi alasan perbedaan nilai tanah, daya tarik tersebut bisa berupa kemudahan mencapai lokasi - lokasi tertentu, topografi, kondisi alam sekitar, ketersediaan sumber daya, keadaan sosial dan masih banyak lagi daya tarik lain yang bisa meningkatkan nilai dari tanah tersebut.

Kenaikan nilai tanah juga sering terjadi ketika adanya wacana mengenai suatu proyek pembangunan infrastruktur jalan pada lokasi tertentu karena dengan dibangunnya infrastruktur menjadikan tingkat kehidupan masyarakat semakin berkembang serta kebutuhan masyarakat akan lahan baru juga turut meningkat yang mengakibatkan adanya perubahan nilai tanah (Putra, 2011). Pola perubahan nilai tanah juga sering berubah terpengaruh oleh faktor lainnya, dengan melakukan studi 
kasus lebih lanjut pada perubahan nilai tanah akibat proyek pembangunan Jalan Lingkar Luar Timur diharapkan dapat memberi gambaran pola peningkatan nilai tanah yang lebih jelas. Sebagai pembanding dampak perubahan nilai tanah yang di sebabkan jalan baru JLLT digunakan Jl. Muhammad Noer yang telah lebih lama beroperasi, guna melihat adanya faktor lain penyebab perubahan nilai tanah.

Dari rangkuman pendahuluan diatas didapatkan tujuan penelitian sebagai berikut:

1. Untuk mengetahui pengaruh yang diakibatkan oleh pembangunan Jalan Lingkar Luar Timur terhadap nilai tanah di sekitarnya.

2. Untuk memberikan gambaran pola perubahan nilai tanah di sekitar proyek pembangunan Jalan Lingkar Luar Timur.

3. Membuat model pendugaan untuk mempermudah dalam melihat gambaran perubahan nilai tanah.

Adapun harapan penulis penelitian ini dapat bermanfaat sebagai berikut:

1. Dapat mengetahui seberapa besar pengaruh pembangunan Jalan Lingkar Luar Timur terhadap nilai tanah di sekitarnya.

2. Dapat menjadi pertimbangan penilaian terhadap nilai tanah di sekitar pembangunan Jalan Lingkar Luar Timur

\section{METODE PENELITIAN}

Data nilai tanah yang digunakan dalam penelitian ini adalah data harga tanah yang didapat dari Badan Pengelolaan Keuangan dan Pajak Daerah (BPKPD) Kota Surabaya. Data yang didapat dari Badan Pengelolaan Keuangan dan Pajak Daerah (BPKPD) Kota Surabaya berupa data nilai tanah tahun 2015-2019 dalam bentuk peta dengan format JPG. Dikarenakan data yang diperoleh dalam format gambar maka perlu dilakukan digitasi. Digitasi merupakan bagian dari proses pembuatan peta digital yang secara umum dapat diartikan sebagai proses pengubahan data analog ke dalam format digital. Digitasi dalam penelitian ini bertujuan untuk memudahkan dalam penyatuan dan pengukuran data sehingga data dapat dianalisis lebih mudah.

Penganalisisan data pada penelitian ini dibagi menjadi dua yaitu analisis dengan membuat grafik hubungan dan analisis dengan menggunakan regresi linier. Analisis grafik dilakukan dengan tujuan untuk mempermudah melihat hubungan yang terjadi antara nilai tanah dan jarak lokasi nilai tanah terhadap lokasi pembangunan dan CBD (Central Bussines District). Sedangkan analisis regresi sederhana bertujuan untuk melihat besaran pengaruh yang ditimbulkan pembangunan jalan terhadap nilai tanah di sekitarnya. Adapun alur penelitian yang dipakai dalam pelaksanaan penelitian ini digambarkan pada gambar berikut:

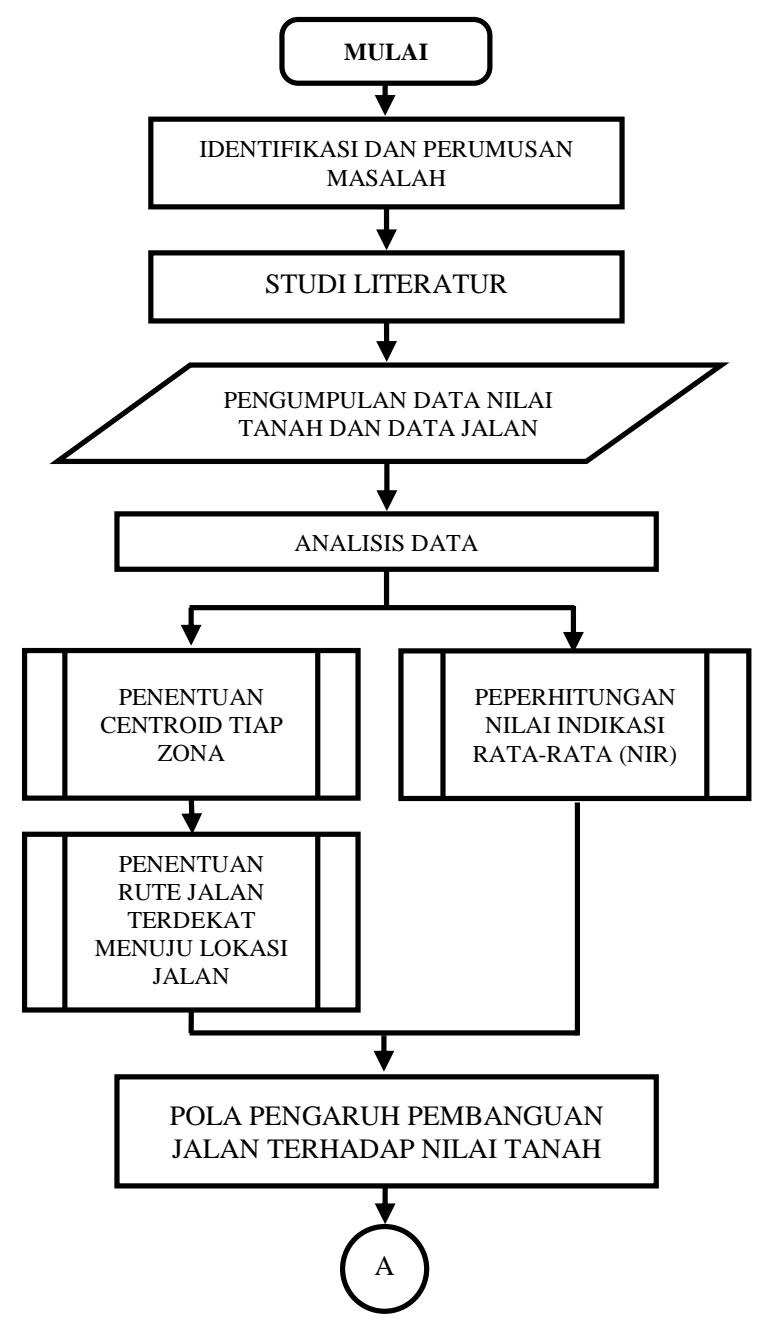




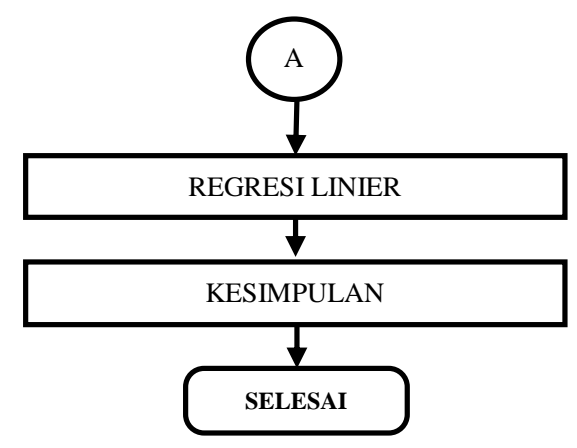

Gambar 1.

Bagan Alir Penelitian

\section{HASIL DAN PEMBAHASAN}

Penelitian ini berada di Kelurahan Bulak, Tanah Kali Kedinding, Kedung Cowek, dan Tambak Wedi, Karena wilayah ke-empat kelurahan tersebut dinilai memenuhi untuk dijadikan lokasi penelitian jika ditinjau dari lokasinya yang dekat dengan pembangunan JLLT (Jalan Lingkar Luar Timur).

Berdasarkan data yang diperoleh dari BPKPD diketahui jika tiap kelurahan terbagi menjadi beberapa zona yang dibatasi oleh garis yang telah ditentukan, dari data empat kelurahan tersebut dapat di identifikasi sebagai berikut:

1. Kelurahan bulak terbagi menjadi 21 ZNT (Zoengan kode B01-B21.

2. Kelurahan Tanah Kali Kedinding terbagi menjadi 25 ZNT (Zona Nilai Tanah) dan diberi penomoran dengan kode K01-K21

3. Kelurahan Kedung Cowek terbagi menjadi 8 ZNT (Zona Nilai Tanah) dan diberi penomoran dengan kode $\mathrm{C} 01-\mathrm{C} 08$

4. Kelurahan bulak terbagi menjadi 7 ZNT (Zona Nilai Tanah) dan diberi penomoran dengan kode T01-T07

Pada penelitian ini, dikarenakan data yang diperoleh dalam format gambar maka perlu dilakukan digitasi.

Tahap pertama yang dilakukan sebelum digitasi adalah pemberian referensi yang dapat dilakukan dengan cara georeferensi dengan menggunakan aplikasi pemetaan. Georeferensi memerlukan data raster yang memiliki referensi spasial, data tersebut berfungsi sebagai acuan untuk mendapatkan nilai koordinat yang digunakan sebagai penentu titik kontrol. Dalam penelitian ini digunakan peta dari openstreetmap dan google earth sebagai acuan pemberian referensi spasialnya.

Tahap selanjutnya setelah dilakukan georeferensi adalah digitasi atau penggambaran ulang peta yang awalnya dalam bentuk analog menjadi gambar vektor dengan menggunakan aplikasi pemetaan. Setelah penggambaran ulang perlu dilakukan pemasukan atribut data harga tanah, sehingga dapat terlihat batasbatas harga tanahnya.

Hasil yang didapat setelah dilakukan digitasi adalah peta harga tanah dalam bentuk vektor yang memiliki referensi spasial sehingga dapat dihitung luasannya dan lebih sesuai dengan kondisi di lapangan karena telah dikalibrasi dengan citra satelit dari google earth.

Pada peta harga tanah tiap zona memiliki satu sampel harga tanah bahkan lebih sehingga perlu dilakukan pengolahan data untuk mendapatkan satu nilai tanah yang mewakili zona tersebut atau bisa disebut dengan NIR (Nilai Indikasi RataRata). Perhitungan NIR tersebut dapat dilakukan dengan persamaan berikut:

$$
\mathrm{NIR}=\frac{\left(\mathrm{X}_{1} \times \mathrm{LX}_{1}\right)+\left(\mathrm{X}_{2} \times \mathrm{LX}_{2}\right)+\left(\mathrm{X}_{3} \times \mathrm{LX}_{3}\right)}{\Sigma \mathrm{LX}}
$$

Keterangan:

$\mathrm{X}_{1}$ : Harga tanah 1

$\mathrm{X}_{2}$ : Harga tanah 2

$\mathrm{LX}_{1}$ : Luas tanah harga 1

$\mathrm{LX}_{2}$ : Luas tanah harga 2

$\Sigma$ LX : Total luas tanah

Hasil dari perhitungan NIR tersebut kemudian dipetakan sehingga didapatkan peta NIR (Nilai Indikasi Rata-Rata) seperti yang ditunjukan seperti gambar berikut: 


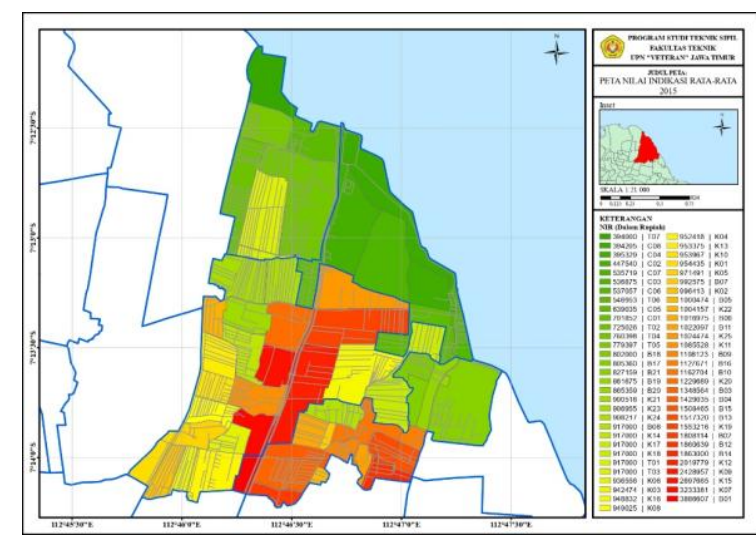

Gambar 2.

Peta NIR (Nilai Indikasi Rata-Rata) 2015

Dari peta NIR 2015 dapat dilihat pada tahun 2015, NIR terkecil berada di zona T07 dengan nilai Rp 394,000 dan NIR terbesar di zona $\mathrm{B} 01$ dengan nilai $\mathrm{Rp}$ $3,886,607$.

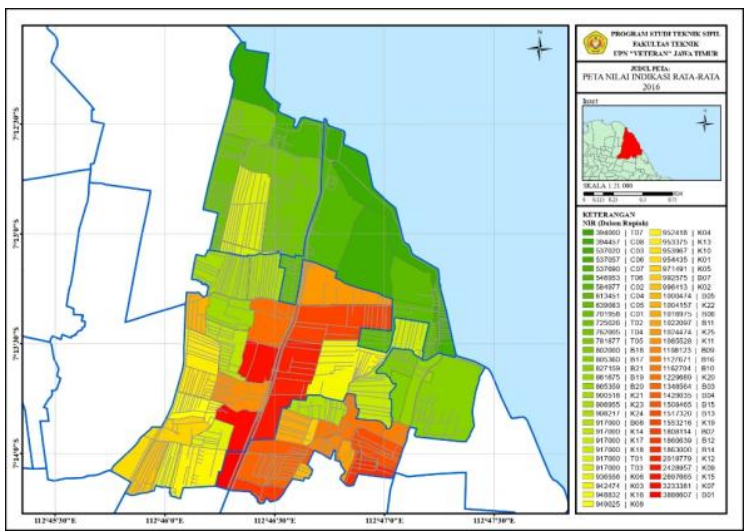

Gambar 3.

Peta NIR (Nilai Indikasi Rata-Rata) 2016

Dari peta NIR 2016 dapat dilihat pada tahun 2016 hanya terjadi sedikit perubahan pada nilai tanah dari 2015, dimana NIR terkecil berada di zona T07 dengan nilai $\mathrm{Rp}$ 394,000 dan NIR terbesar di zona B01

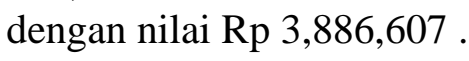

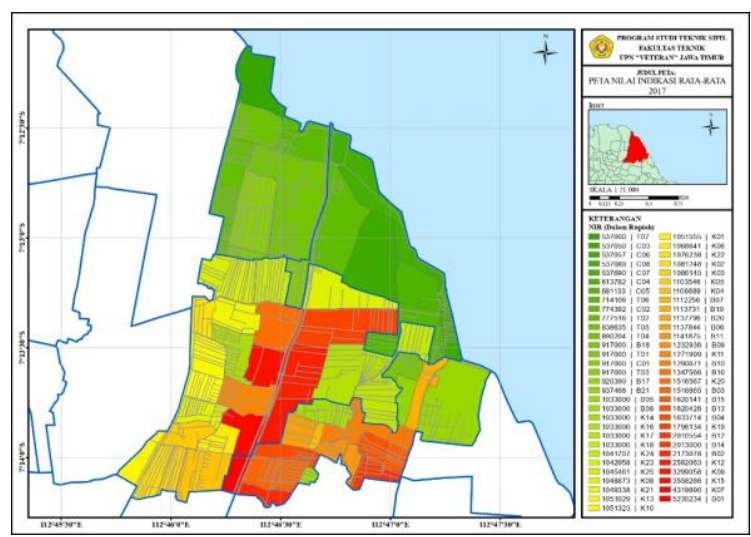

Gambar 4.

Peta NIR (Nilai Indikasi Rata-Rata) 2017

Dari peta NIR 2017 dapat dilihat pada tahun 2015 mengalami cukup banyak perubahan NIR dimana nilai NIR terkecil berada di zona T07 meningkat ke nilai $\mathrm{Rp}$ 573,000 dan NIR terbesar berada di zona B01 meningkat ke nilai Rp 5,230,234.

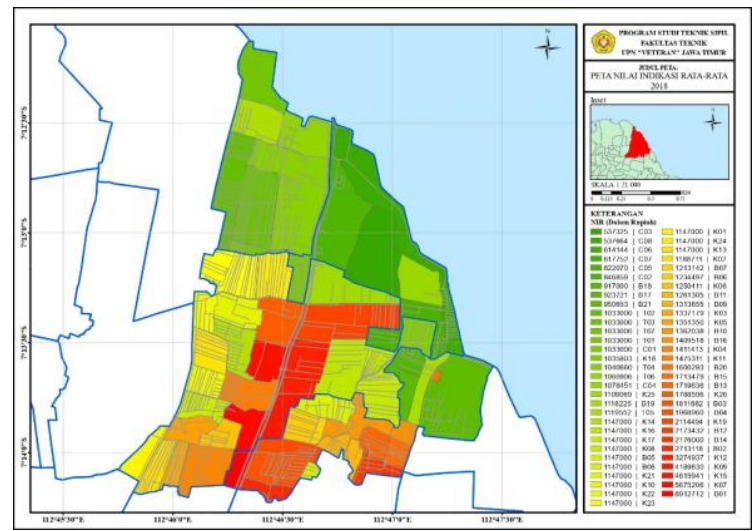

Gambar 5.

Peta NIR (Nilai Indikasi Rata-Rata) 2018

Dari peta NIR 2018 dapat dilihat pada tahun 2018 juga mengalami cukup banyak perubahan NIR dimana nilai NIR terkecil berubah ke zona $\mathrm{C} 03$ dan meningkat ke nilai $\mathrm{Rp} 573,325$ sedangkan NIR terbesar tetap berada di zona B01 dan meningkat ke nilai $\operatorname{Rp} 6,912,712$. 


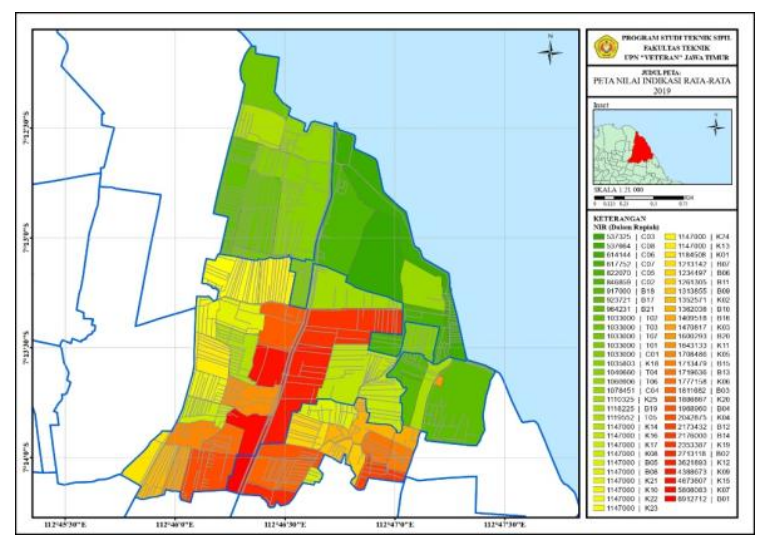

Gambar 6.

Peta NIR (Nilai Indikasi Rata-Rata) 2019

Dari peta NIR 2019 dapat dilihat pada tahun 2019 hanya terjadi sedikit perubahan pada nilai tanah dari 2018, dimana NIR terkecil tetap berada di zona C03 dengan nilai $\mathrm{Rp}$ 573,325 dan NIR terbesar juga tetap di zona B01 dengan nilai $\mathrm{Rp}$ $6,912,712$.

Setelah pemetaan nilai tanah selesai, selanjutnya penentuan jarak terdekat yang diukur dari tiap titik tengah zona nilai tanah menuju Lokasi Pembangunan Jalan Lingkar Luar Timur dengan syarat melalui jalan yang dapat dilalui kendaraan bermotor. Untuk memudahkan menentukan jalan atau rute terdekat digunakan bantuan aplikasi google map.

Tahap pertama yang dilakukan adalah penentuan centroid atau titik tengah dari zona nilai tanah. Tahap ini dilakukan menggunakan aplikasi pemetaan dengan cara mengubah data polygon zona nilai tanah menjadi point sehingga terbentuk titik tengah zona atau centroid. Setelah penentuan centroid selesai maka didapat peta letak centroid yang dapat dilihat pada gambar berikut:

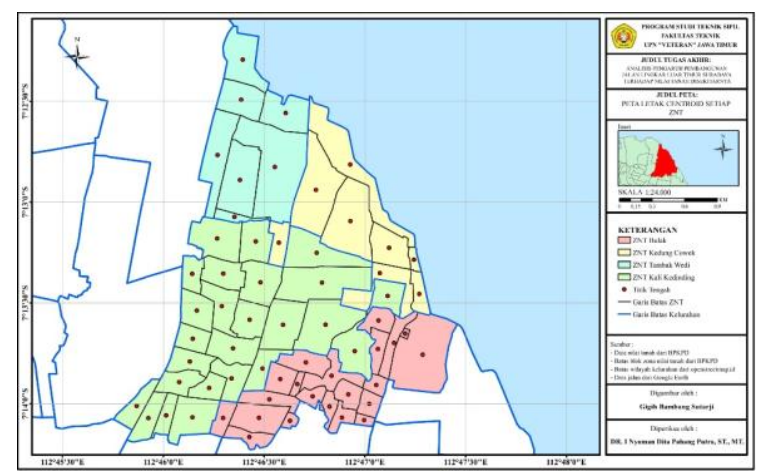

Gambar 7.

Peta Letak Centroid

Tahap kedua adalah menentukan rute terdekat menggunakan bantuan aplikasi google map dengan cara memasukan koordinat centroid pada google map sebagai titik awal lalu di arahkan menuju lokasi pembangunan JLLT (Jalan Lingkar Luar Timur) . Rute jarak terdekat menuju JLLT (Jalan Lingkar Luar Timur) dapat dilihat pada gambar berikut:

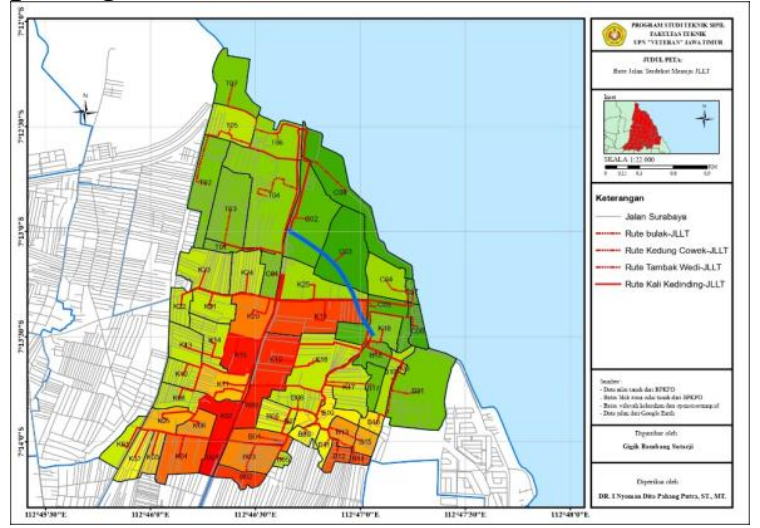

Gambar 8.

Peta Rute menuju JLLT

Melihat adanya akses jalan lain di dekat lokasi pembangunan JLLT (Jalan Lingkar Luar Timur) yang telah beroperasi lebih lama yaitu Jl. Muhammad Noer atau jalan menuju Jembatan Suramadu dan diperkirakan juga mempengaruhi nilai tanah disekitarnya maka dihitung juga jarak lokasi tanah menuju Jl. Muhammad Noer sebagai data pembanding. Adapun peta rute terdekat menuju J1. Muhammad Noer dapat dilihat pada gambar berikut: 


\section{FAKULTAS TEKNIK UNIVERSITAS WIRARAJA SUMENEP - MADURA}

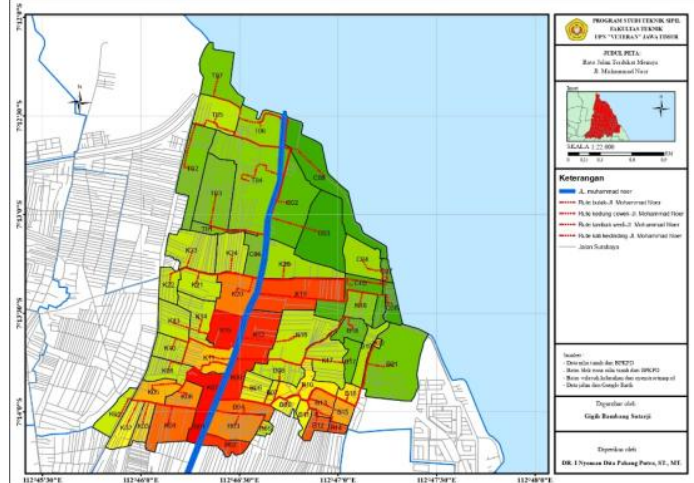

Gambar 9.

Peta Rute menuju Jl. Muhammad Noer

Tabel 1

Rekapitulasi Data

\begin{tabular}{|c|c|c|c|c|c|c|c|c|}
\hline \multirow{2}{*}{$\begin{array}{l}\text { KODE } \\
\text { ZNT }\end{array}$} & \multirow{2}{*}{$\begin{array}{l}\text { Jarak Menuju } \\
\text { JLLT (Km) }\end{array}$} & \multirow{2}{*}{$\begin{array}{c}\text { Jarak Menuju Jl. } \\
\text { Mohammad Noer } \\
(\mathbf{K m})\end{array}$} & \multicolumn{6}{|c|}{ NIR (Rupiah) } \\
\hline & & & 2015 & 2016 & 2017 & 2018 & 2019 & Rata-Rata \\
\hline B1 & 3.040 & 0.048 & $3,886,607$ & $3,886,607$ & $5,230,234$ & $6,912,712$ & $6,912,712$ & $5,365,775$ \\
\hline B2 & 2.263 & 0.312 & $1,808,114$ & $1,808,114$ & $2,173,078$ & $2,713,118$ & $2,713,118$ & $2,243,109$ \\
\hline B3 & 2.023 & 0.370 & $1,348,564$ & $1,348,564$ & $1,516,865$ & $1,811,682$ & $1,811,682$ & $1,567,471$ \\
\hline B4 & 1.840 & 0.338 & $1,429,035$ & $1,429,035$ & $1,633,714$ & $1,968,960$ & $1,968,960$ & $1,685,941$ \\
\hline B5 & 1.834 & 0.659 & $1,000,474$ & $1,000,474$ & $1,033,000$ & $1,147,000$ & $1,147,000$ & $1,065,590$ \\
\hline B6 & 1.533 & 0.462 & $1,016,975$ & $1,016,975$ & $1,137,844$ & $1,234,497$ & $1,234,497$ & $1,128,158$ \\
\hline B7 & 1.441 & 0.591 & 992,575 & 992,575 & $1,112,256$ & $1,213,142$ & $1,213,142$ & $1,104,738$ \\
\hline B8 & 1.301 & 0.833 & 917,000 & 917,000 & $1,033,000$ & $1,147,000$ & $1,147,000$ & $1,032,200$ \\
\hline B9 & 1.286 & 0.744 & $1,108,123$ & $1,108,123$ & $1,232,936$ & $1,313,855$ & $1,313,855$ & $1,215,378$ \\
\hline B10 & 1.030 & 0.930 & $1,162,704$ & $1,162,704$ & $1,290,671$ & $1,362,038$ & $1,362,038$ & $1,268,031$ \\
\hline B11 & 1.417 & 1.079 & $1,022,097$ & $1,022,097$ & $1,141,875$ & $1,261,305$ & $1,261,305$ & $1,141,736$ \\
\hline B12 & 1.543 & 1.204 & $1,860,639$ & $1,860,639$ & $2,010,554$ & $2,173,432$ & $2,173,432$ & $2,015,739$ \\
\hline B13 & 1.403 & 1.068 & $1,517,320$ & $1,517,320$ & $1,620,426$ & $1,719,636$ & $1,719,636$ & $1,618,867$ \\
\hline B14 & 1.716 & 1.381 & $1,863,000$ & $1,863,000$ & $2,013,000$ & $2,176,000$ & $2,176,000$ & $2,018,200$ \\
\hline B15 & 1.618 & 1.282 & $1,508,465$ & $1,508,465$ & $1,620,141$ & $1,713,479$ & $1,713,479$ & $1,612,806$ \\
\hline B16 & 1.161 & 1.443 & $1,127,671$ & $1,127,671$ & $1,347,566$ & $1,409,518$ & $1,409,518$ & $1,284,389$ \\
\hline B17 & 1.077 & 1.156 & 805,360 & 805,360 & 920,390 & 923,721 & 923,721 & 875,710 \\
\hline B18 & 0.266 & 1.492 & 802,000 & 802,000 & 917,000 & 917,000 & 917,000 & 871,000 \\
\hline B19 & 0.681 & 2.010 & 861,675 & 861,675 & $1,113,731$ & $1,118,225$ & $1,118,225$ & $1,014,706$ \\
\hline B20 & 0.548 & 2.118 & 865,359 & 865,359 & $1,137,796$ & $1,600,293$ & $1,600,293$ & $1,213,820$ \\
\hline B21 & 1.005 & 2.142 & 827,159 & 827,159 & 937,468 & 950,653 & 964,231 & 901,334 \\
\hline $\mathrm{C} 01$ & 0.999 & 0.092 & 701,852 & 701,958 & 917,000 & $1,033,000$ & $1,033,000$ & 877,362 \\
\hline $\mathrm{C} 02$ & 0.204 & 0.301 & 447,540 & 584,977 & 774,392 & 846,859 & 846,859 & 700,125 \\
\hline $\mathrm{C03}$ & 0.144 & 0.530 & 536,875 & 537,020 & 537,050 & 537,325 & 537,325 & 537,119 \\
\hline $\mathrm{CO} 4$ & 0.724 & 1.501 & 395,329 & 613,451 & 613,782 & $1,078,451$ & $1,078,451$ & 755,893 \\
\hline $\mathrm{C} 05$ & 0.233 & 0.912 & 639,035 & 639,083 & 681,133 & 822,070 & 822,070 & 720,678 \\
\hline C06 & 0.638 & 1.457 & 537,057 & 537,057 & 537,057 & 614,144 & 614,144 & 567,891 \\
\hline $\mathrm{C} 07$ & 0.637 & 1.312 & 535,719 & 537,690 & 537,690 & 617,752 & 617,752 & 569,321 \\
\hline $\mathrm{C} 08$ & 1.076 & 1.130 & 394,205 & 394,457 & 537,089 & 537,664 & 537,664 & 480,216 \\
\hline T01 & 2.677 & 0.558 & 917,000 & 917,000 & 917,000 & $1,033,000$ & $1,033,000$ & 963,400 \\
\hline T02 & 2.715 & 1.446 & 725,026 & 725,026 & 777,516 & $1,033,000$ & $1,033,000$ & 858,714 \\
\hline T03 & 2.966 & 0.840 & 917,000 & 917,000 & 917,000 & $1,033,000$ & $1,033,000$ & 963,400 \\
\hline T04 & 2.147 & 0.800 & 760,398 & 762,005 & 890,204 & $1,040,660$ & $1,040,660$ & 898,785 \\
\hline T05 & 2.069 & 0.797 & 779,397 & 781,877 & 838,635 & $1,119,552$ & $1,119,552$ & 927,803 \\
\hline T06 & 1.323 & 1.323 & 546,953 & 546,953 & 714,106 & $1,060,906$ & $1,060,906$ & 785,965 \\
\hline T07 & 2.042 & 2.042 & 394,000 & 394,000 & 537,000 & $1,033,000$ & $1,033,000$ & 678,200 \\
\hline K01 & 3.479 & 1.029 & 954,435 & 954,435 & $1,051,555$ & $1,147,000$ & $1,184,508$ & $1,058,386$ \\
\hline K02 & 3.397 & 0.948 & 996,413 & 996,413 & $1,081,248$ & $1,188,711$ & $1,352,571$ & $1,123,071$ \\
\hline K03 & 3.256 & 0.808 & 942,474 & 942,474 & $1,086,145$ & $1,337,179$ & $1,470,817$ & $1,155,818$ \\
\hline K04 & 3.010 & 0.565 & 952,418 & 952,418 & $1,106,889$ & $1,411,413$ & $2,042,875$ & $1,293,203$ \\
\hline K05 & 2.982 & 0.985 & 971,491 & 971,491 & $1,103,546$ & $1,351,350$ & $1,708,486$ & $1,221,273$ \\
\hline K06 & 2.800 & 0.807 & 936,556 & 936,556 & $1,068,641$ & $1,250,411$ & $1,777,158$ & $1,193,864$ \\
\hline K07 & 2.366 & 0.113 & $3,233,381$ & $3,233,381$ & $4,319,890$ & $5,675,206$ & $5,808,083$ & $4,453,988$ \\
\hline K08 & 2.738 & 0.926 & 949,025 & 949,025 & $1,048,873$ & $1,147,000$ & $1,147,000$ & $1,048,184$ \\
\hline
\end{tabular}

\section{Jurnal "MITSU" Media Informasi Teknik Sipil UNIJA Volume 9, No. 2, Oktober 2021 e-ISSN 2685-9173}




\begin{tabular}{|c|c|c|c|c|c|c|c|c|}
\hline \multirow{2}{*}{$\begin{array}{l}\text { KODE } \\
\text { ZNT }\end{array}$} & \multirow{2}{*}{$\begin{array}{l}\text { Jarak Menuju } \\
\text { JLLT }(\mathbf{K m})\end{array}$} & \multirow{2}{*}{$\begin{array}{l}\text { Jarak Menuju JI. } \\
\text { Mohammad Noer } \\
(\mathbf{K m})\end{array}$} & \multicolumn{6}{|c|}{ NIR (Rupiah) } \\
\hline & & & 2015 & 2016 & 2017 & 2018 & 2019 & Rata-Rata \\
\hline K09 & 1.624 & 0.096 & $2,428,957$ & $2,428,957$ & $3,299,058$ & $4,189,830$ & $4,388,673$ & $3,347,095$ \\
\hline K10 & 2.575 & 0.767 & 953,967 & 953,967 & $1,051,323$ & $1,147,000$ & $1,147,000$ & $1,050,651$ \\
\hline K11 & 2.158 & 0.228 & $1,085,528$ & $1,085,528$ & $1,271,999$ & $1,475,311$ & $1,643,133$ & $1,312,300$ \\
\hline K12 & 1.116 & 0.194 & $2,019,779$ & $2,019,779$ & $2,582,063$ & $3,274,937$ & $3,621,893$ & $2,703,690$ \\
\hline K13 & 2.426 & 0.898 & 953,375 & 953,375 & $1,051,029$ & $1,147,000$ & $1,147,000$ & $1,050,356$ \\
\hline K14 & 2.320 & 0.800 & 917,000 & 917,000 & $1,033,000$ & $1,147,000$ & $1,147,000$ & $1,032,200$ \\
\hline K15 & 1.916 & 0.393 & $2,697,665$ & $2,697,665$ & $3,558,266$ & $4,615,941$ & $4,673,607$ & $3,648,629$ \\
\hline K16 & 1.264 & 0.595 & 948,832 & 948,832 & $1,033,000$ & $1,147,000$ & $1,147,000$ & $1,044,933$ \\
\hline K17 & 0.907 & 0.931 & 917,000 & 917,000 & $1,033,000$ & $1,147,000$ & $1,147,000$ & $1,032,200$ \\
\hline K18 & 0.280 & 1.235 & 917,000 & 917,000 & $1,033,000$ & $1,035,803$ & $1,035,803$ & 987,721 \\
\hline K19 & 0.549 & 0.391 & $1,553,216$ & $1,553,216$ & $1,796,134$ & $2,114,494$ & $2,353,387$ & $1,874,089$ \\
\hline K20 & 1.495 & 0.355 & $1,229,689$ & $1,229,689$ & $1,516,567$ & $1,788,596$ & $1,886,867$ & $1,530,282$ \\
\hline K21 & 1.856 & 0.718 & 900,518 & 900,518 & $1,049,338$ & $1,147,000$ & $1,147,000$ & $1,028,875$ \\
\hline K22 & 2.094 & 0.955 & $1,004,157$ & $1,004,157$ & $1,076,238$ & $1,147,000$ & $1,147,000$ & $1,075,710$ \\
\hline K23 & 2.018 & 0.875 & 906,955 & 906,955 & $1,042,958$ & $1,147,000$ & $1,147,000$ & $1,030,174$ \\
\hline K24 & 1.595 & 0.455 & 908,217 & 908,217 & $1,041,707$ & $1,147,000$ & $1,147,000$ & $1,030,428$ \\
\hline K25 & 0.540 & 0.412 & $1,024,474$ & $1,024,474$ & $1,045,461$ & $1,109,069$ & $1,110,325$ & $1,062,760$ \\
\hline
\end{tabular}

Untuk mempermudah melihat hubungan nilai tanah terhadap jarak lokasi tanah menuju JLLT (Jalan Lingkar Luar Timur) dan Jl. Muhammad Noer pada tahun 2015 sampai 2019 maka dibuatlah grafik hubungan nilai tanah menggunakan nilai tanah rata-rata tahun 2015 sampai 2019 seperti yang di tunjukan pada grafik berikut:

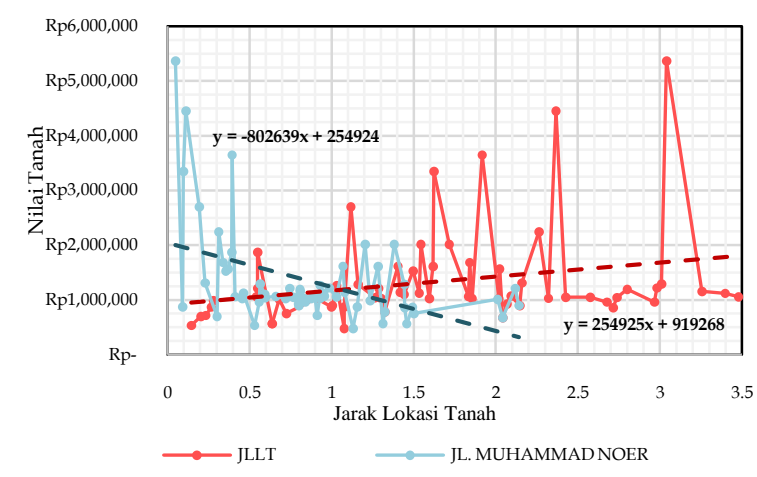

Gambar 10.

Grafik Analissis HubunganNilai Tanah

Rata-rata Tahun 2015-2019

Pada grafik Analisis Hubungan Nilai Tanah Rata-rata Tahun 2015-2019 tersebut bisa dilihat pada garis grafik hubungan Jarak lokasi pembangunan JLLT (Jalan Lingkar Luar Timur) berpengaruh positif atau setiap bertambahnya jarak maka nilai tanah juga akan meningkat. Sedangkan pada garis grafik hubungan jarak lokasi Jl. Muhammad Noer berpengaruh negatif atau setiap bertambahnya jarak maka nilai tanah akan menurun.

Untuk mengetahui besaran pengaruh yang disebabkan keberadaan pembangunan JLLT (Jalan Lingkar Luar Timur) dan Jl. Muhammad Noer terhadap nilai tanah maka perlu dilakukan analisis regresi. Analisis regresi yang digunakan adalah analisis regresi linier sederhana di mana hanya ada satu variabel terikat dan satu variabel bebas, jadi jarak lokasi tanah menuju JLLT (Jalan Lingkar Luar Timur) dan JL. Muhammad Noer secara bergantian akan di analisis sebagai variabel terikat untuk mengetahui mana yang lebih mempengaruhi nilai tanah. analisis regresi linier dalam penelitian ini menggunakan aplikasi pengolah angka dengan memanfaatkan tools data analysis. Data nilai tanah yang digunakan pada analisis adalah nilai tanah rata-rata dari tahun 2015-2019 dan didapat hasil analisis seperti berikut:

Tabel 2.

Hasil Analisis Pengaruh JLLT Terhadap Nilai Tanah

\begin{tabular}{|c|c|l|l|}
\hline \multicolumn{2}{|l|}{ Regression Statistics } \\
\hline Multiple R & 0.252686 & & \\
\hline R Square & 0.06385 & & \\
\hline
\end{tabular}




\begin{tabular}{|c|c|c|c|c|c|c|c|}
\hline \multicolumn{2}{|c|}{ Adjusted R Square } & \multicolumn{2}{|c|}{0.047983} & & & & \\
\hline \multicolumn{2}{|c|}{ Standard Error } & \multicolumn{2}{|c|}{867377.9} & & & & \\
\hline \multicolumn{2}{|c|}{ Observations } & \multicolumn{2}{|c|}{61} & & & & \\
\hline \multicolumn{8}{|l|}{ ANOVA } \\
\hline & & \multicolumn{2}{|c|}{$d f$} & \multicolumn{2}{|c|}{$F$} & \multicolumn{2}{|c|}{ Significance $F$} \\
\hline \multicolumn{2}{|c|}{ Regression } & \multicolumn{2}{|c|}{1} & \multicolumn{2}{|c|}{4.024115} & \multicolumn{2}{|r|}{0.049446} \\
\hline Residu & & \multicolumn{2}{|c|}{5} & & & & \\
\hline \multicolumn{2}{|c|}{ Total } & \multicolumn{2}{|c|}{60} & & & & \\
\hline & \multicolumn{2}{|c|}{ Coefficients } & \multicolumn{2}{|c|}{$\begin{array}{l}\text { Standard } \\
\text { Error }\end{array}$} & \multicolumn{2}{|c|}{$t$ Stat } & $P$-value \\
\hline Intercept & \multicolumn{2}{|c|}{$919,268.1$} & \multicolumn{2}{|c|}{238619.9} & \multicolumn{2}{|c|}{3.85243} & $\begin{array}{c}0.000290 \\
787\end{array}$ \\
\hline $\begin{array}{c}\text { Jarak ke } \\
\text { Lokasi } \\
\text { JLLT }(\mathrm{km})\end{array}$ & \multicolumn{2}{|c|}{254924.9} & \multicolumn{2}{|c|}{127079.9} & \multicolumn{2}{|c|}{2.00602} & $\begin{array}{c}0.049445 \\
853\end{array}$ \\
\hline
\end{tabular}

Pada tabel hasil analisis pengaruh JLLT terhadap nilai tanah dapat dilihat jika hasil $R$ square didapatkan angka 0.06285 yang berarti bahwa variabel $\mathrm{x}$ atau jarak lokasi tanah dengan lokasi pembangunan JLLT dapat menjelaskan $6.28 \%$ terhadap variabel y atau nilai tanah.

Tabel 3.

Hasil Analisis Pengaruh

JL. Muhammad Noer Terhadap Nilai

Tanah

\begin{tabular}{|c|c|c|c|c|c|c|c|}
\hline \multicolumn{8}{|c|}{ Regression Statistics } \\
\hline \multicolumn{2}{|c|}{ Multiple R } & \multicolumn{2}{|c|}{0.456746} & & & & \\
\hline \multicolumn{2}{|c|}{ R Square } & \multicolumn{2}{|c|}{0.208617} & & & & \\
\hline \multicolumn{2}{|c|}{ Adjusted R Square } & \multicolumn{2}{|c|}{0.195204} & & & & \\
\hline \multicolumn{2}{|c|}{ Standard Error } & \multicolumn{2}{|c|}{797,497} & & & & \\
\hline \multicolumn{2}{|c|}{ Observations } & \multicolumn{2}{|l|}{61} & & & & \\
\hline \multicolumn{8}{|l|}{ ANOVA } \\
\hline & & \multicolumn{2}{|c|}{$d f$} & \multicolumn{2}{|c|}{$F$} & \multicolumn{2}{|c|}{ Significance $F$} \\
\hline \multicolumn{2}{|c|}{ Regression } & \multicolumn{2}{|l|}{1} & \multicolumn{2}{|c|}{15.55303} & \multicolumn{2}{|c|}{0.000216} \\
\hline Residu & & 59 & & & & & \\
\hline \multicolumn{2}{|l|}{ Total } & 60 & & & & & \\
\hline & \multicolumn{2}{|c|}{ Coefficients } & \multicolumn{2}{|c|}{$\begin{array}{l}\text { Standard } \\
\text { Error }\end{array}$} & \multicolumn{2}{|c|}{$t$ Stat } & $P$-value \\
\hline Intercept & \multicolumn{2}{|c|}{$2,042,657$} & \multicolumn{2}{|c|}{$204,708.9$} & \multicolumn{2}{|c|}{9,9783} & $\begin{array}{l}2,78878 \mathrm{E} \\
-14\end{array}$ \\
\hline $\begin{array}{c}\text { Jarak ke } \\
\text { Lokasi } \\
\text { JLLT }(\mathrm{km})\end{array}$ & \multicolumn{2}{|c|}{$-802638,9$} & \multicolumn{2}{|c|}{203522,6} & \multicolumn{2}{|c|}{$\overline{3}, 9437$} & $\begin{array}{l}0,0002155 \\
75\end{array}$ \\
\hline
\end{tabular}

Pada tabel hasil analisis pengaruh $\mathrm{Jl}$. Muhammad Noer terhadap nilai tanah dapat dilihat jika hasil $R$ square didapatkan angka 0,208 yang berarti bahwa variabel $\mathrm{x}$ atau jarak lokasi tanah dengan JL. Muhammad Noer dapat menjelaskan $20.8 \%$ terhadap variabel y atau nilai tanah.
Perbedaan besar $R$ square dari hasil analisis regresi linier sederhana menunjukan perbedaan pengaruh yang jarak lokasi tanah, di mana pengaruh $\mathrm{Jl}$. Muhammad Noer terhadap nilai tanah lebih besar daripada pengaruh JLLT terhadap nilai tanah yaitu sebesar $20.8 \%$ > $6.28 \%$.

\section{KESIMPULAN}

Analisis dan pengamatan yang telah dilakukan pada penelitian ini dapat menyimpulkan beberapa hal seperti yang dijelaskan berikut:

1. Berdasarkan analisis menggunakan regresi linier didapatkan pengaruh JLLT (Jalan Lingkar Luar Timur) terhadap nilai tanah sebesar $6.28 \%$ dan pengaruh jalan Muhammad Noer sebesar 20.8\%, sehingga dapat disimpulkan bahwa Jalan Muhammad Noer lebih besar pengaruhnya terhadap nilai tanah di lokasi studi.

2. Berdasarkan analisis dan pengamatan menggunakan grafik dapat disimpulkan hubungan faktor jarak JLLT (Jalan Lingkar Luar Timur) berpengaruh positif terhadap nilai tanah atau jika jarak lokasi tanah semakin besar maka nilai akan meningkat. Hasil ini berbanding terbalik dengan konsep dasar nilai tanah di mana seharusnya hubungan faktor jarak berpengaruh negatif terhadap nilai tanah atau jika jarak lokasi tanah semakin besar maka nilai akan menurun.

3. Berdasarkan analisis menggunakan regresi linier dari data nilai tanah ratarata tahun 2015-2019, pengaruh faktor jarak JLLT (Jalan Lingkar Luar Timur) menghasilkan koefisien determinasi (R2) sebesar 0,0628 didapatkan model pendugaan $\mathrm{y}=254924.9 \mathrm{x}+919268.1 \mathrm{dan}$ 
untuk pengaruh faktor jarak Jalan Muhammad Noer menghasilkan (R2) sebesar 0.208 didapatkan model pendugaan $\quad \mathrm{y}=-802638.9 \mathrm{x}+2042657$. Sehingga JLLT (Jalan Lingkar Luar Timur) masih belum mempengaruhi nilai tanah pada lokasi studi, sedangkan Jalan Muhammad Noer telah mempengaruhi nilai tanah pada lokasi studi.

\section{DAFTAR PUSTAKA}

Faiq, N.,(2019), Kebut JLLT, Pemkot Surabaya Bebaskan Lahan di 14 Kelurahan, SURYA, pp. 1-2.

Harum, M., Sutriani., (2017), Pengaruh Pembangunan Jalan Tol Sutami Terhadap Nilai Lahan Disekitarnya, National Academic Jurnal Of Architecture, 4(1), pp. 66-73.

Putra, INDP.,(2011), Faktor - Faktor Yang Mempengaruhi Perubahan Nilai Tanah dan Bangunan Pada Suatu Properti, Jurnal Teknik Sipil KERN, $1(1)$, pp. 52-62.

Rahayu, H.C.,(2009), Analisa Nilai Tanah Terhadap Lingkungan Kampus Politeknik Pasis Pengairan, Jurnal Aptek, 1(1), pp. 62-69. 